\title{
CONSTITUTIONAL ENVIRONMENTAL RIGHTS: AN UNDER-UTILISED RESOURCE
}

\author{
LORETTA FERIS
}

\begin{abstract}
This article supports the principled proposition that all human beings have a fundamental right to an environment that is ecologically sound and does not threaten health or wellbeing. It also takes the position that we need a solid and detailed understanding of the content of the environmental right in the South African Constitution. It is particularly imperative that such content reflect the particular context within which the right operates. The article argues, however, that the content and value of South Africa's environmental right, remains largely undefined. It reviews a number of decisions which have provided opportune moments to give content to the right, and in this regard focuses on two areas where jurisprudence may enhance the application of an environmental right. These developing principles of environmental law and interrogating the relationship between the environmental right and other constitutionally-entrenched rights.
\end{abstract}

\section{INTRODUCTION}

In 1987 the Brundtland Commission proposed that 'all human beings have a right to an environment adequate for their health and well-being.'. This proposition captured concerns over increasing deterioration of environmental quality and integrity and in essence suggested that an anthropocentric approach to the environment may assist in finding solutions to the impending crisis of environmental degradation. More recently the United Nations developed a Draft Declaration of Human Rights and the Environment, ${ }^{2}$ which included the principle that '[a]ll persons have the right to a secure, healthy and ecologically sound environment. This right and other human rights, including civil, cultural, economic, political and social rights, are universal, interdependent and indivisible, ${ }^{3}$

Since 1994 a number of similar 'soft law' declarations and statements have seen the light of day, but we have seen no general, comprehensive international treaty on human rights and the environment which obliges states to protect a constitutionally entrenched right to a healthy environment. Notwithstanding this deficiency in international law, numerous countries around the world have

Associate Professor of Law, University of Pretoria. This article, developed during my period as sabbatical fellow at the South African Institute for Advanced Constitutional, Public, Human Rights and International Law (SAIFAC), is based on a paper presented at the 5th Annual IUCN Academy of Environmental Law Colloquium, Parati, Brazil, June 2007. It was also presented at a seminar at SAIFAC in July 2007. I would like to thank Prof Louis Kotze (NWU) and Dr Stuart Woolman (UP) for their helpful comments on an earlier draft.

1 Report of the World Commission on Environment and Development: Our Common Future (1987).

2 Available at $<$ http://www1.umn.edu/humanrts/instree/1994-dec.htm>.

3 Ibid. Part II Principle 2. 
opted for a constitutional provision for environmental protection in some form or another. ${ }^{4}$

Section 24 of the Constitution of the Republic of South Africa, 1996 (hereafter 'the Constitution') provides for one of the most comprehensive environmental rights. Yet we have little understanding of the nature of the right and how it operates vis-à-vis other rights. While some South African cases have referred to the environmental right and have even attempted some analysis of the right, very few have endeavoured to conceptualise the right in an in-depth manner. This paucity in jurisprudence may feed criticism related to indeterminacy and obscurity of an environmental right.

This article therefore focuses on two areas where jurisprudence may enhance the application of an environmental right. These are the development of principles of environmental law and interrogating the relationship between the environmental right and other constitutionally-entrenched rights. In doing so, it provides a brief conceptualisation of environmental rights and addresses some of the points of critique which have been levelled against environmental rights.

\section{Conceptualising Environmental Rights}

There is little agreement in the international arena on the way in which an environmental right should be conceptualised. In this respect one can refer to two central positions. The biocentric or ecocentric argument follows the belief that the environment has intrinsic value which entitles it to an existence regardless of the interest of human beings. ${ }^{5}$ This viewpoint emphasises the interrelationship and interdependence of animal and plant life systems. ${ }^{6}$ Since the basic claim is that all species are equal, this notion displaces humans from the centre of creation. The alternative, more anthropocentric, view emphasises the status of humans in the natural hierarchy regarding care for the earth. It is believed that the earth should be preserved for a variety of reasons related to human interests. This includes serving as a stockpile of genetic diversity for agricultural, medical and other purposes, and as material for scientific study, recreation, aesthetic enjoyment and spiritual inspiration. ${ }^{7}$

\section{(a) A biocentric approach to environmental rights}

Proponents of this approach view the richness and diversity of life as values in themselves and hold that human beings have no right to reduce these resources, except to satisfy their basic needs. They therefore perceive the need

4 Constitutional environmental rights can inter alia be found in the Constitutions of Austria, Ethiopia, Germany, Greece, Namibia, Nigeria, Portugal, Spain and Switzerland.

5 Examples of these publications are R Carson Silent Spring (1962), E Goldsmith Blueprint for Survival (1972) and R Erlich The Population Bomb (1968).

6 Bookchin argues as follows: 'Each species, be it in a form of bacteria or deer, is knitted together in a network of interdependence, however indirect the links may be': M Bookchin The Ecology of Freedom (1982) 26. See also F Capra 'Deep Ecology: A New Paradigm' in G Sessions (ed) Deep Ecology for the 21st Century (1995) 19-25.

$7 \quad$ P Bunyard \& F Morgan-Grenville The Green Alternative: Guide to Good Living (1987) 284. 
for cultural diversity and diversity in social arrangements as preconditions to the survival of the planet. An essential element in the transformation towards an equitable relationship between human beings and nature is the denunciation of dualisms, such as mind and body, culture and nature, subject and object. Biocentrists argue that conceptions of 'self and other', when formulated in terms of interdependencies and connectedness, stimulate an acceptance of difference. They therefore believe the following:

- The well-being and flourishing of human and non-human life on earth have value in themselves. These values are independent of the usefulness of the non-human world for human purposes.

- Richness and diversity of life forms contribute to the realisation of these values and are also values in themselves.

- Humans have no right to reduce this richness and diversity except to satisfy basic needs. ${ }^{8}$

Biocentrists therefore argue against the notion of rights and reject the value that a rights doctrine may have in reforming the way humans view and deal with the environment. It is said that individual rights create rights holders 'who exist as empty vessels, as no one (thing) in particular in relation to other rights holders of the same type'. ${ }^{9}$ For example, if one frames nature as a rights holder, it removes all other experiential realities of nature; it is not beautiful, alive, or part of us. They also reject the notion that the natural world must rely on legal language in order to be seen and heard. ${ }^{10}$ They therefore argue for the idea of 'rightness' as opposed to rights, where one acknowledges the 'intrinsic rightness of non-human existence and sensibilities and express that acknowledgement in human behaviour ..., or complete the humanisation of the planet by making all living things unwitting participants in a prosthetic moral hierarchy."

A related yet less stringent view, in which nature serves as rights holder, has also gained some popularity. In 1972 Christopher Stone authored his provocative work on rights, 'Should Trees have Standing?.' ${ }^{2}$ In it he criticises the traditional common law approach to the environment and to environmental damage that holds that the environment, for example a polluted stream, is not a rights holder with standing and is essentially dependent on a rights-holder - a riparian who suffers damage and exposes the failings of this approach. ${ }^{13}$ He suggests that it ignores the moral worth of the environment and of natural objects. He therefore offers an alternative approach that provides for guardi-

8 A Naess 'The Deep Ecology Movement: Some Philosophical Aspects' in Sessions (ed) (note 6 above) 64 .

9 C Giagnocavo \& H Goldstein 'Law Reform or World Reform: The Problem of Environmental Rights' (1989-1990) 35 McGill Law Journal 346-362.

10 Ibid 365

11 J Livingston 'Rightness or Rights' (1984) 22 Osgoode Hall Law Journal 309-321.

12 C Stone 'Should Trees Have Standing? — Towards Legal Rights for Natural Objects' (1972) 45 Southern California LR 450

13 Ibid 459-463. 
anship of natural objects: where a friend of a natural object which believes the object to be under threat can apply to the court for the appointment of such a guardian to secure an effective voice for the environment. ${ }^{14}$ His ideas were based on the rejection of the utilitarian notion of environmental protection based on human interest in conservation, and essentially embraced a biocentric approach to environmentalism.

\section{(b) An anthropocentric approach to environmental rights}

An alternative approach to environmental rights focuses on the interconnectedness between humans and the environment and the important role that humans fulfil in nature. Two main approaches can be distinguished in the way in which 'environment' is conceptualised: $:^{15}$

- an instrumental or strongly anthropocentric approach, which holds that the earth should be viewed as a source of (mainly economic) resources that should be conserved with the specific aim of maintaining its usefulness for humans;

- a weak anthropocentric position, which does recognise the central locale that humans adopt in nature and the ways in which humans find value in the utility of the earth, but also recognises the value of the environment independent of its usefulness for human purposes.

Some of the foremost proponents of a weak anthropocentric position to environmentalism are social ecologists. Bookchin, for example, argues that social ecology is rooted in the balance of nature, process, diversity, spontaneity, freedom and wholeness. ${ }^{16}$ With their emphasis on balance, social ecologists reject the mechanistic, instrumental outlook that nature is a resource for humans and humans are a resource for the economy. ${ }^{17}$ They also reject the domination of humans over nature and of humans over other humans. Instead, social ecology emphasises the human interdependence with the non-human nature. This view challenges the notion of hierarchy in nature that places humans at the top of the pyramid and holds that each species is equal to and interconnected with other species. It does, however, recognise that humans have the ability to transform nature. This human capacity is not considered to be unlimited, but is counteracted by nature's ability to transform humans, which demonstrates the interdependence between humans and nature.

Social ecology also focuses on the implication of systems of economic production for both humans and the environment. It criticises both capitalism and state socialism for their capacity to disrupt nature. It argues for a world in which basic human needs are fulfilled through an economic restructuring

15 See, for example, J McCormick Reclaiming Paradise: The Global Environmental Movement (1991).

16 See Bookchin (note 6 above) for a detailed analysis of social ecology.

17 C Merchant Radical Ecology (1992) 144. 
that is environmentally sustainable. ${ }^{18}$ It therefore supports the stabilisation of the world's population, but does not agree with programmes that result in genocide, racism or disregard for human rights. Instead, it supports economic programmes which provide for basic needs in order to bring about the equalisation of quality of life in developed as well as developing countries.

Similarly to biocentrists, social ecologists are calling for a major transformation of people's views and of governmental policies towards the environment. In contrast with the more limited perspective of biocentrics, however, they see the solution to environmental problems as rooted in sustainable development and social justice. Their emphasis is on the human condition as a basis for transformation, as opposed to the deep ecologists' goal of transforming the world view and reclaiming spiritual connections to the earth.

The power that humans have to dominate the environment can therefore be used to the advantage of the human population. This second approach recognises the ability of humans to manipulate the environment to the sustained advantage of humans. It provides a different dimension to the relationship between humans and the environment and humans within the environment. It creates the basis for humans laying claim to an environment that is not polluted and degraded. This is a claim lodged not against the environment, but against other human beings and their institutions in recognition of the ability of humans to manipulate the environment in a way that may be detrimental not only to the environment itself, but also to human beings. It is within this view that one can substantiate an argument for a constitutional right that guarantees citizens their ability to live in an environment that is adequate for their health and wellbeing.

The creation of a constitutionally-guaranteed environmental right incorporates an integrated approach to environmental problems. It discards the dualist belief that places conservation in the domain of non-human species, while lack of environmental quality is considered to be a problem that concerns humans. Moreover, a constitutional environmental right acknowledges the profound effect that environmental degradation may have on humans. It also acknowledges the detrimental impact that humans may have on the environment. It recognises that environmental problems have the ability to threaten potentially everyone in an indiscriminate way, and that they can be so severe as to present a threat to the security of states. ${ }^{19}$ Ultimately, continued environmental degradation may threaten not only the health, livelihoods and lives of humans, but our continued existence. Constitutional entrenchment of environmental rights in the form of a human right therefore serves as a basic condition for human existence. ${ }^{20}$

18 Ibid.

19 T Hayward Constitutional Environmental Rights (2005) 5.

20 The idea of an environmental right as foundation for basic human existence was confirmed in a recent Constitutional Court judgment. Ngcobo J remarked in Fuel Retailers Association of Southern Africa v Director General Environmental Management, Department of Agriculture, Conservation and Environment, Mpumalanga Province 2007 (6) SA 4 (CC) para 102 that ' $[\mathrm{t}]$ he importance of the protection of the environment cannot be gainsaid. Its protection is vital to the enjoyment of the other rights contained in the Bill of Rights; indeed, it is vital to life itself. It must therefore be protected for the benefit of the present and future generations'. 
III A Critique of Protecting the Right to a Healthy Environment in A Bill of Rights

A rights approach to environmental protection is not without criticism. ${ }^{21}$ It is argued, for example, that a constitutional environmental right may undermine the separation of powers in the state, since this right could displace the powers of the legislature and the executive with regard to environmental matters and transfer these powers to the judiciary instead. Courts are then charged with the atypically judicial responsibility and policy-making power to determine appropriate standards for environmental protection. ${ }^{22}$ While the ideal of a strict separation of powers may be a noble one, it is unattainable in a modern democracy in an absolute form and it is also not necessarily desirable. The emphasis should rather be on developing an appropriate system of checks and balances to ensure accountability, responsibility and transparency as well as an interaction among the different organs of state. ${ }^{23}$ Constitutions charge judiciaries, as guardians of the Bill of Rights, with a variety of duties. The Constitution, for example, does not require the rights it entrenches only to be respected, but also to be protected, promoted and fulfilled. ${ }^{24}$ The courts are therefore also required to safeguard and facilitate these 'active' duties assigned to the state. This necessarily entails an expansion of the powers of the judiciary and enhances its influence in political matters.

The concern has also been raised that constitutional entrenchment of an environmental right which sets too high a standard of environmental protection may pose a political threat to the legal system as a whole. This could result, so it is argued, in the unconstitutionality of undesirably vast tracts of existing legislation as well as the imposition of positive duties far beyond the (material) capacity of the state. ${ }^{25}$ But is it not true, one may ask, that the very notion of a democratic state premised on a supreme constitution which includes a Bill of Rights, at any rate alludes to some measure of activism on the part of the state in order to guarantee effectively (other) fundamental rights? Traditional civil and political rights, such as the right to vote, also require positive state action and make budgetary demands in order to ensure their fulfilment. Social justice may demand a particularly activist state in order to fulfil the basic needs of citizens. On the other hand, however, basic freedom rights such as the rights to privacy or freedom of expression can be sensible only to citizens whose basic (material) needs have been met.

21 For a more detailed discussion see T Van Reenen 'Constitutional Protection of the Environment: Fundamental (Human) Right or Principle of State Policy?' (1997) 4 South African J of Environmental Law \& Policy 279-281.

22 Ibid.

23 S Liebenberg 'Socio-economic Rights' in Chaskalson et al (eds) (1998) Constitutional Law of South Africa 41-8.

24 Section 7(2) of the Constitution.

25 Van Reenen (note 21 above). 
A third point of criticism relates to the generality of the words used to circumscribe essential components of an environmental right. The meaning of concepts such as a 'healthy' or an 'adequate' environment, 'well-being' and 'sustainability' remains elusive. This could largely be ascribed to the fact that the environment is a dynamic entity and is constantly changing, primarily owing to manipulation by human beings. In other words, how does one measure an adequate environment? Do citizens living in a polluted, heavily-industrialised urban area enjoy an adequate environment? Can it be measured against their rural counterparts residing in a relatively unspoiled countryside? If one considers the constantly rising rate of development, is there a corresponding drop in the level of environmental quality and as such a diminution of the environmental right? In other words, how does one establish some kind of threshold of quality below which the right may be violated?

These questions illustrate that environmental rights differ from other human rights, such as the right to life or the right to human dignity, in that there cannot always be a universal standard for a 'healthy environment'. The approach therefore has been to define the right more broadly by adopting general terms such as 'an environment that is adequate' or as in the South African Constitution, 'an environment that is not harmful to health and well-being'. This general framing of the right should not necessarily be an obstacle to judicial interpretation of the right, as risk standards may be set through administrative and/or legislative means. ${ }^{26}$ In other words, acceptable levels of risk, harm or pollution must be defined for a specific country in light of present scientific standards and, more specifically, in light of its socio-economic conditions. ${ }^{27}$ The South African right makes this clear by including in the framing of the right a duty on government to provide for these standards by way of legislative or other means. Section 24 of the South African Constitution provides:

Everyone has the right -

(a) to an environment that is not harmful to their health or well-being; and

(b) to have the environment protected, for the benefit of present and future generations, through reasonable legislative and other measures that-

(i) prevent pollution and ecological degradation;

(ii) promote conservation; and

(iii) secure ecologically sustainable development and use of natural resources while promoting justifiable economic and social development.

26 JW Nickel 'The Human Right to a Safe Environment: Philosophical Perspectives on its Scope and Justification' (1993) 18 Yale J of Int Law 281-285.

27 Ibid. Nickel argues that in this respect there is no difference between the environmental right and rights regarding inhumane or degrading punishment, effective remedy and arbitrary detention or arrest as they also amount to broad normative standards that require national measures to provide content to the right. 
In essence the section has two general aims. Paragraph (a) guarantees a healthy environment to everyone in general, while paragraph (b) mandates the state to take certain measures in order to realise the guarantee proclaimed in the first part of the section. ${ }^{28}$ The legislature has paid serious attention to the duty created in s 24(b), and has enacted a number of statutes which attempt to protect environmental resources and regulate harmful impacts on the environment. ${ }^{29}$ The legislation incorporates international environmental principles such as the duty of care principle and the 'polluter pays' principle, and creates liability for environmental damage. ${ }^{30}$ It furthermore provides for compliance with and enforcement of environmental laws. ${ }^{31}$ In addition, legislation has been enacted to give effect to procedural rights in the Constitution. These are rights that are indispensable to the implementation and enforcement of environmental rights

28 'Environment' in I Currie \& J De Waal The Bill of Rights Handbook 5 ed (2006) 521, 522. See also BP Southern Africa (Pty) Ltd v MEC for Agriculture, Conservation and Land Affairs 2004 (5) SA $124(\mathrm{~W})$.

29 The National Environmental Management Act 107 of 1998 (NEMA) established a new form of environmental regulation and environmental governance in South Africa. NEMA aims to:

- define overarching and generic principles in which sectoral-specific legislation is embedded;

- enhance co-operative environmental governance amongst fragmented line ministries;

- provide for a broad flexible framework to address environmental issues and to respond to changes in socio-economic and ecological parameters

Legislation addressing specific sectoral environmental concerns has been enacted in areas such as biodiversity: the National Environmental Management: Protected Areas Act 57 of 2003 ('NEM:PAA'), the National Environmental Management: Biodiversity Act 10 of 2004 ('NEM:BA') and the National Forests Act 84 of 1998 ('NFA'); air quality: the National Environmental Management: Air Quality Act 39 of 2004 ('AQA'); protection of marine resources: the Marine Living Resources Act 18 of 1998 ('MLRA'); protection of water resources: the National Water Act 36 of 1998 ('NWA'); and the regulation of the impact of mining and energy on the environment: the Minerals and Petroleum Resources Development Act 28 of 2002 ('MPRDA'). Legislation dealing with waste management is currently in the process of being drafted. See the National Environmental Management: Waste Management Bill, 2006 (published under General Notice 1832 in GG 29487 of January 2007).

30 Section 2(4)(p) of NEMA states that "the costs of remedying pollution, environmental degradation and consequent adverse health effects and of preventing, controlling or minimising further pollution, environmental damage or adverse health effects must be paid for by those responsible for harming the environment'. Section 28 gives effect to this principle and obliges a party to take reasonable measures to prevent pollution, stop or minimise pollution and undertake remediation in respect thereof. This duty of care extends to pollution or degradation of all environmental media (air, water and soil), and applies to owners of land, persons in control of land and persons with the right to use land. Similar liability provisions can be found in sectoral legislation on water (s 19 of the NWA), mining and petroleum resources (s 38 of the MPRDA) and biodiversity (s 69 with regard to activities relating to alien species and s 73 with regard to activities relating to invasive species of the NEM:BA). Liability may also stem from environmental damage resulting from the use of GMOs (s 17 of the Genetically Modified Organisms Act 15 of 1997).

31 Section 31 of NEMA establishes an enforcement unit, the Environmental Management Inspectorate. According to ss 31B, 31C and 31D, Environmental Management Inspectors (EMIs) are tasked with the monitoring and enforcement of designated environmental legislation. 
and include the rights to freedom of association, ${ }^{32}$ access to information, ${ }^{33}$ just administrative action, ${ }^{34}$ and access to courts. ${ }^{35}$

Legislation therefore to a large extent addresses concerns regarding ambiguity of rights language and uncertainty relating to interpretation which have been levelled against environmental rights. Legislation cannot, however, account for all instances where confusion may reign and also cannot provide a remedy for every instance in which an individual or community's environmental right may be infringed. In a constitutional democracy the judiciary plays an important role in enforcing constitutional rights. As such, it falls on the judiciary to use its powers of judicial review to assess the act and conduct of the legislature and executive for consistency with the Constitution. In a Constitution such as the South African Constitution, which provides for

32 Section 18 of the Constitution provides that everyone has the right to freedom of association.

33 Section 32 of the Constitution states:

'(1) Everyone has the right of access to-

(a) any information held by the state; and

(b) any information that is held by another person and that is required for the exercise or protection of any rights.

(2) National legislation must be enacted to give effect to this right, and may provide for reasonable measures to alleviate the administrative and financial burden on the state.'

The Promotion of Access to Information Act 2 of 2000 (PAIA) has been enacted to give effect to s 32 .

34 Section 33 of the Constitution provides for procedural fairness of governmental action. It provides as follows:

'(1) Everyone has the right to administrative action that is lawful, reasonable and procedurally fair.

(2) Everyone whose rights have been adversely affected by administrative action has the right to be given written reasons.

(3) National legislation must be enacted to give effect to these rights, and must-

(a) provide for the review of administrative action by a court or, where appropriate, an independent and impartial tribunal;

(b) impose a duty on the state to give effect to the rights in subsections (1) and (2); and

(c) promote an efficient administration.'

35 Section 34 of the Constitution provides for access to courts. It has been argued that this right guarantee three distinct rights to rights holders: First, it creates a right of access to a court or other tribunal or forum. Second, it requires tribunals or forums other than courts to be independent and impartial when they are involved in the resolution of legal disputes. Third, it is a due process guarantee, requiring the legal disputes to which it applies to be decided in a fair and public hearing: 'Access to Courts' in Currie \& De Waal (note 28 above) 703-704. This right is vital in the field of environmental law where it is often environmental watchdogs which keep those who violate environmental laws accountable by taking court action against them. However, the prohibitive costs of litigation can limit the extent to which this form of environmental public interest litigation can go ahead. Section 32 of NEMA has attempted to address this in part by giving the courts a discretion not to award costs against public interests litigants who fail to secure the relief sought in respect of alleged environmental law violation, if the court is of the opinion that the person or group of persons acted reasonably out of a concern for the public interest or in the interest of protecting the environment, and had made due efforts to use other means reasonably available for obtaining the relief sought. Yet, in the decision of Biowatch v Registrar: Genetic Resources 2005 (4) SA 111 (T), a watchdog organisation was penalised for the way in which it chose to exercise the right to access to information to access information regarding GMO field trials, despite the fact that the organisation was partially successful in its litigation. 
the horizontal application of human rights, ${ }^{36}$ it is the role of the judiciary to enforce the right against natural or juristic persons. ${ }^{37}$ It is through this process of judicial review that courts can provide content to the right and address problems such as vagueness and lack of definition. Within the broader scope of human rights interpretation, the judiciary has certainly seized the challenge of defining equally vague terms such as equal protection, due process and cruel and unusual punishment. ${ }^{38}$ It is therefore only fit that the judiciary should similarly develop environmental rights by providing substance to seemingly abstract terms, or at least confirm the existence within domestic law of significant environmental principles such as 'polluter pays'.

\section{UndER-UtilisATION OF ENVIRONMENTAL RightS}

When one examines South African jurisprudence, there seems to be a marked dearth in cases where the environmental right has been fully utilised and clearly interpreted. This may be ascribed to a variety of reasons including the novelty of the subject matter, a failure by litigating lawyers to raise s 24 , or a lack of judicial familiarity with environmental law. ${ }^{39}$ In surveying some of the cases where s 24 has been raised, one cannot but notice a number of missed opportunities, which could have resulted in sound jurisprudence in an area of law that is in much need of clarity and content. In this respect, this article would like to highlight two areas which offered prospects for development of jurisprudence aimed at providing interpretative clarity: providing contextual

36 Section 8 of the Constitution provides:

(1) The Bill of Rights applies to all law, and binds the legislature, the executive, the judiciary and all organs of state.

(2) A provision of the Bill of Rights binds a natural or a juristic person if, and to the extent that, it is applicable, taking into account the nature of the right and the nature of any duty imposed by the right.

37 With regard to the role of the courts in judicial review, the Constitutional Court in Bato Star Fishing (Pty) Ltd v Minister of Environmental Affairs and Tourism 2004 (4) SA 490 (CC) observed: 'In treating the decisions of administrative agencies with the appropriate respect, a court is recognising the proper role of the Executive within the Constitution. In doing so a court should be careful not to attribute to itself superior wisdom in relation to matters entrusted to other branches of government. A court should thus give due weight to findings of fact and policy decisions made by those with special expertise and experience in the field. The extent to which a court should give weight to these considerations will depend upon the character of the decision itself, as well as on the identity of the decision-maker. A decision that requires an equilibrium to be struck between a range of competing interests or considerations and which is to be taken by a person or institution with specific expertise in that area must be shown respect by the courts. Often a power will identify a goal to be achieved, but will not dictate which route should be followed to achieve that goal. In such circumstances a court should pay due respect to the route selected by the decision-maker. This does not mean, however, that where the decision is one which will not reasonably result in the achievement of the goal, or which is not reasonably supported on the facts or not reasonable in the light of the reasons given for it, a court may not review that decision. A court should not rubber-stamp an unreasonable decision simply because of the complexity of the decision or the identity of the decision-maker.' Paras 48-49.

38 J Fernandez 'State Constitutions, Environmental Rights Provisions and the Doctrine of Selfexecution: A Political Question?' (2003) 17 Harvard Environmental LR 333-372.

39 Other commentators have also criticised the South African judiciary for its failure to interpret s 24 adequately. See M Kidd 'Greening the Judidiciary' 3 PER (2006) for a more general critique regarding the failure of the judiciary to properly apply environmental laws. 
content to the principle of sustainable development, and clarifying the relationship between s 24 and other human rights, both from a competing interest and from a related interdependence perspective.

\section{(a) Developing the principle of sustainable development in the South African context}

There is clearly a need to interpret a number of concepts in environmental law, especially those concepts such as sustainable development which may be controversial, vague or uncertain. More importantly, it is imperative that we understand these concepts in the context in which we find ourselves. South Africa has a very specific history, one that has shaped the way in which the Constitution has been framed. Section 1 of the Constitution sets out the founding values of the Republic and describes South Africa as 'one sovereign, democratic state founded on the values of human dignity, the achievement of equality and the advancement of human rights and freedoms'. ${ }^{40}$ The values endorsed by the Constitution give content to the vision of the Constitution, which is primarily one of transforming an erstwhile unjust society. ${ }^{41}$ Equality, for example, is central to the process of redress and transformation in South Africa. In this respect the Constitutional Court has noted:

The South African Constitution is primarily and emphatically an egalitarian Constitution. The supreme laws of comparable constitutional states may underscore other principles and rights. But in the light of our own particular history, and our vision for the future, a Constitution was written with equality at its centre. Equality is our Constitution's focus and its organising principle. ${ }^{42}$

The Constitution therefore sets the stage for how we should understand certain environmental principles or concepts. When the opportunity arises to engage in this process, it should ideally be grabbed with both hands.

While the concept of sustainable development is fairly new to South African law, as early as 1971 a Rhodesian decision recognised that the principle of inter-generational equity can have the effect of limiting other rights, such as property rights. In King $v$ Dykes ${ }^{43}$ MacDonald ACJ stated:

The idea which prevailed in the past that ownership of land conferred the right on the owner to use his land as he pleased is rapidly giving way in the modern world to the more responsible conception that an owner must not use his land in a way which may prejudice his neighbours or the community in which he lives, and that he holds his land in trust for future generations. Legislation dealing with such matters as town and country planning, the conservation of natural resources, and the prevention of pollution, and regulations designed to ensure that proper farming practices are followed, all bear eloquent testimony of the existence of this more civilised and enlightened attitude towards the rights conferred by ownership of land. ${ }^{44}$

41 C Albertyn \& B Goldblatt 'Facing the Challenge of Transformation: Difficulties in the Development of an Indigenous Jurisprudence of Equality' (1998) 14 SAJHR 248-249.

42 President of the Republic of South Africa v Hugo 1997 (4) SA 1 (CC) para 74.

431971 (3) SA 540 (RA).

44 Ibid 545G-H. 
This judgment mirrors the very early sentiments of the Brundtland Report, which describes sustainable development as development which meets the needs of the present generation without compromising the ability of future generations to meet their own needs. ${ }^{45}$ According to the Report, this definition not only gives effect to the notion that priority must be given to the needs of the poor, but it also captures the limitations to development imposed by the present state of technology and social organisation on the environment's ability to meet present and future needs. ${ }^{46}$ The definition therefore suggests an inherent link between social and environmental needs and the need for technological advancement and development. An imbalance among these elements, where global patterns of development put the environment under pressure, places the earth in crisis. This principle of integration between three pillars, environment protection, economic development, and social needs, is now widely recognised as a core element of sustainable development. ${ }^{47}$

This principle was also recognised in BP Southern Africa (Pty) Ltd v MEC for Agriculture, Conservation, Environment and Land Affairs. ${ }^{48}$ The applicant sought the review and setting aside of a decision by the Gauteng Provincial Department of Agriculture, Conservation, Environment and Land Affairs (GDACE) to refuse the applicant's application in terms of s 22(1) of the Environment Conservation $\mathrm{Act}^{49}$ (ECA) for authorisation to develop a filling station on one of its properties. The Department based its refusal, inter alia, on environmental concerns. The applicant contended, however, that its application was refused not because the new filling station itself posed a danger to the environment, but rather because there were already two other filling stations within three kilometres of the applicant's site, and the Department regarded it as unacceptable to allow proliferation of filling stations where existing filling stations were economically vulnerable to more competition. It argued that under the guise of 'environmental concerns', the department was instead seeking to regulate the economy on the basis of what were essentially economic considerations unrelated to the environment.

The court explored the concept of sustainable development and in so doing considered the wide definition of 'environment' employed by ECA which defines it in s 1 as: 'the aggregate of surrounding objects, conditions and influences that influence the life and habits of man or any other organism or collection of organisms'. According to the court, the broad definition of 'environment' would include all conditions and influences affecting the life and habits of man, which would also include socio-economic conditions and influences. ${ }^{50}$ With regard to the state's obligation under s 24(b), the court held that the department was obliged to develop an integrated environmental

47 See for example P Sands Principles of International Law (2003) 153. See also D Tladi Sustainable Development in International Law: An Analysis of Key Enviro-economic Instruments (2007) 58.

482004 (5) SA 124 (W)

49 Act 73 of 1989.

50 Note 48 above $145 \mathrm{E}$. 
management programme, which took cognisance of a wide spectrum of considerations, including international conventions and approaches as a result of the broad and extensive definition of 'environment' in ECA, which, inter alia, includes the consideration of socio-economic conditions.

The socio-economic considerations of sustainable development received more detailed (and eloquent) attention in a recent Constitutional Court judgment. In Fuel Retailers Association of Southern Africa v Director General Environmental Management, Department of Agriculture, Conservation and Environment, Mpumalanga Province, ${ }^{52}$ the decision of the authorities to grant an environmental authorisation for the construction of a proposed filling station was challenged. The applicant specifically contended that the provincial authorities failed to consider the socio-economic impact of the proposed development. As in $B P$, the court stressed the inter-connected nature of environmental, social and economic considerations within the context of sustainable development and stated that:

The Constitution recognises the interrelationship between the environment and development; indeed it recognises the need for the protection of the environment whilst at the same time it recognises the need for social and economic development. It envisages that environmental considerations will be balanced with socio-economic considerations through the ideal of sustainable development. ${ }^{53}$

It places the duty to balance potentially conflicting principles on 'those who enforce and implement the Constitution' on the basis of proportionality. Yet it stresses at the same time that the principle of sustainable development may actually serve the purpose of facilitating 'the achievement of the balance'.

While the court clarified that sustainable development requires integrating the often contesting demand of economic development, social development and environmental protection, the question remains: how do we interpret sustainable development in a country which faces large scale poverty and where such a clear and unequivocal need for economic and social development is present?

The definition set out by the Brundtland report captures the need for equity within generations as well as between generations. The principle of intragenerational equity (equity within generations) is essentially an approach that takes cognisance of the distributional demands of social justice. This is premised on the belief that distributional inequalities are causally responsible for a great deal of environmental degradation. ${ }^{55}$ Reducing inequalities can therefore be held to be a necessary means of achieving sustainability. This is of particular importance in the South African context, given the enduring nature of socio-economic inequalities in the country.

55 T Benton 'Ecology, Community and Justice' in T Hayward \& J O’Neill (eds) Justice, Property and the Environment, Social and Legal Perspectives (1997) 17-23. 
In Minister of Public Works v Kyalami Ridge Environmental Association, ${ }^{56}$ the court had an opportunity to assess and delineate the concept of sustainable development within the particular context of the South African economical landscape. ${ }^{57}$ In this particular case, heavy rains had led to extensive flooding and the subsequent destruction of the homes of approximately 300 people. The homeless flood victims were forced to live in tents erected on some municipal land, in overcrowded and unhealthy conditions without sufficient water and sanitation. It was decided to establish a transit camp on state land (at Leeuwkop Prison) as an emergency measure to provide temporary accommodation for flood victims until suitable, permanent housing could be provided. Residents of land adjoining the proposed site for the transit camp (the Kyalami residents) brought an urgent application in the High Court for an interdict restraining the respondents from proceeding with the establishment of an informal settlement. The Kyalami residents argued that the government action was in contravention of the relevant town planning scheme as well as the applicable environmental legislation. They based their contention on the damage that would be done to the environment if a transit camp were to be established at Leeuwkop, and in doing so relied, among others, on their rights under s 24. The High Court granted an interim interdict and ordered government to comply with the necessary environmental legislation. Government appealed to the Constitutional Court, arguing that the appeal raised important constitutional considerations. One of the flood victims also intervened in the application, contending that the flood victims had a constitutional right to adequate housing.

While at first glance the case seems to raise competing interests, being the right of access to adequate housing versus the environmental right, it was actually an opportunity to assess the state's duty in the context of its s 24(b) obligations and in particular, its duties in relation to sustainable development. As mentioned above, s 24(b) mandates the state to apply measures which will prevent pollution and ecological degradation, promote conservation, and secure ecologically-sustainable development and the use of natural resources, while promoting justifiable economic and social development ${ }^{58}$ The Kyalami residents' contentions essentially rested on the argument that the state negated this obligation by not providing for integrated environmental management of the site, including conducting an environmental impact assessment as required by environmental legislation. It was, however, never argued as such, or the court simply did not consider sustainable development in this manner.

57 It has been argued that the case involved two competing rights, the environmental right in s 24 and the right to adequate housing as set out in s 26(1), which states that 'everyone has the right to have access to adequate housing'. See M Van der Linde \& E Basson 'Environment' in Woolman et al (eds) Constitutional Law of South Africa 2 ed (2005). The authors miss, however, the fact that the applicants did not ever deny the victims' right to access to adequate housing [para 28], and as such there was never an obligation on the court to address competing rights.

58 For a discussion of the concept 'justifiable development' see GM Ferreira 'Volhoubare Ontwikkeling, Regverdige Ontwikkeling en die Fundamentele Reg op 'n Skoon en Gesonde Omgewing' (1999) 3 SALJ 436-437. 
In essence, when fulfilling its mandate as set out in s 24(b), the state will have to make sure that it does so in a way which balances not only environmental considerations, but also social and economic considerations, in other words, sustainable development. In this regard, the South African reality is that the health and well-being of the lower-income strata of the population are at a bigger risk than those of the middle-income and wealthy sectors. ${ }^{59}$ The environmental concerns of the affluent sectors largely rest on quality of life and well-being, which is threatened by atmospheric pollution, noise, congested transport, and the like. The environmental concerns of the poor - water pollution, lack of sanitation, overcrowding, distance from places of work, and the like - can have a much greater effect and may threaten their health and livelihood. The poor often suffer the double bind of the lack of access to basic services such as clean water, housing and health care, and a disproportionate share of the burden of environmental degradation. A case can be made that distributional inequalities in economic and social welfare are causally responsible for a great deal of environmental degradation. There is therefore a nexus between poverty, under-development and the degradation of the environment. It is the poor who are most vulnerable to environmental degradation. Reducing economic inequalities and addressing social welfare concerns are often held to be necessary means of achieving sustainability. ${ }^{60}$ But when is it appropriate to do so at the expense of environmental concerns? The Kyalami Ridge case missed an opportunity to assess sustainable development against the background of the competing interests inherent in the concept itself.

\section{(b) The relationship between s 24 and other human rights}

(i) Competing values

The nature of constitutional human rights is such that they do not operate in isolation, but may at times give rise to competing values. In such situations there is a need for guidance from the court to indicate how one may meet the challenge of competing rights and to gain an understanding of the place of the right to a healthy environment vis-à-vis other rights such as property rights, for example.

Competing rights are not foreign to constitutional rights litigation. Section 36(2) of the South African Constitution clearly states that rights can be justifiably limited in terms of 'any other provision of the Constitution'. Rights may therefore have a limiting effect on each other and may be used justifiably to infringe another right. It raises the question, however: what is the extent of the environmental right? In what instances can it operate to limit another right, and vice versa? This issue was addressed in In Re 
Kranspoort Community. ${ }^{61}$ The case concerned a claim for restitution of rights in land, in terms of the Restitution of Land Rights Act, ${ }^{62}$ by the Kranspoort Community. The claim was disputed by the owner of the land and some of the objections raised were based on environmental concerns. It was argued that the area was environmentally sensitive and that the use at that time promoted the protection of the environment. Restoration would serve only to prejudice the sustainable management of the farm from an environmental perspective. The case pitted environmental considerations against section 35 property rights and more specifically rights stemming from restoration etc.

The Court is given a wide discretion to grant relief in respect of a valid land claim. ${ }^{63}$ In granting relief the court can consider a number of factors, including the feasibility of such restoration. ${ }^{64}$ Although the concept of feasibility is not defined in the Restitution of Land Rights Act, the test to be applied according to the Court is whether the restoration to the claimant of the right in land in question will be possible and practical, with regard to:

(a) the nature of the land and the surrounding environment at the time of dispossession;

(b) the nature of the claimant's use at the time of the dispossession;

(c) the changes which have taken place on the land itself and in the surrounding area since the dispossession;

(d) any physical or inherent defects in the land;

$612000(2)$ SA 124 (LCC).

62 Act 22 of 1994

63 Section 35 of the Restitution of Land Rights Act states:

(1) The Court may order-

(a) the restoration of land, a portion of land or any right in land in respect of which the claim or any other claim is made to the claimant or award any land, a portion of or a right in land to the claimant in full or in partial settlement of the claim and, where necessary, the prior acquisition or expropriation of the land, portion of land or right in land: Provided that the claimant shall not be awarded land, a portion of land or a right in land dispossessed from another claimant or the latter's ascendant, unless-

(i) such other claimant is or has been granted restitution of a right in land or has waived his or her right to restoration of the right in land concerned; or

(ii) the Court is satisfied that satisfactory arrangements have been or will be made to grant such other claimant restitution of a right in land;

(b) the State to grant the claimant an appropriate right in alternative state-owned land and, where necessary, order the State to designate it;

(c) the State to pay the claimant compensation;

(d) the State to include the claimant as a beneficiary of a State support programme for housing or the allocation and development of rural land;

(e) the grant to the claimant of any alternative relief.

(2) The Court may in addition to the orders contemplated in subsection (1) -

(a) determine conditions which must be fulfilled before a right in land can be restored or granted to a claimant. ...

(3) An order contemplated in subsection (2)(c) shall be subject to such conditions as the Court considers necessary to ensure that all the members of the dispossessed community shall have access to the land or the compensation in question, on a basis which is fair and non-discriminatory towards any person, including a tenant, and which ensures the accountability of the person who holds the land or compensation on behalf of the community to the members of such community.

Section 33(cA). 
(e) official land use planning measures relating to the area; and

(f) the general nature of the claimant's intended use of the land concerned. ${ }^{65}$

In considering the first aspect of the test, the Court accepted that the area was environmentally sensitive and that the use at that time tended to promote the protection of the environment. It held, however, that if restoration would not prejudice the sustainable management of the farm from an environmental perspective, there should be no reason why the use of the land should hold sway over restoration. ${ }^{66}$ The Court furthermore held that the modern approach to conservation is not to consider protection of the environment as something which must necessarily exclude communities and their activities. ${ }^{67}$ It focuses rather on co-opting communities into the sustainable management of the environment, especially considering that the community is part of the historical heritage of that specific area.

The Court came to this position without explicitly taking s 24 into consideration. This is a pity, given that this type of sound reasoning and an attempt to harmonise competing rights would do much to augment the jurisprudence of s 24. The Court did, however, consider s 24 in using its powers under s 35(2)(c) of the Restitution of Land Rights Act, in prescribing how the restored rights in land were to be held and in imposing such conditions as it considered necessary to ensure that there was equitable access to the restored asset. In this respect it took into account sustainable development considerations. With reference to the risk of unsustainable depletion of renewable resources on the farm, it referred to the need to consider the ability of younger members of the community to have equitable access to the restored asset in the future. ${ }^{68}$ It therefore considered the need of future generations (without expressly referring to it), which relates to inter-generational equity, which can arguably be considered one of the primary components of sustainable development. The Court believed that conditions aimed at eliminating the risk of such depletion were in line with s 24(b) of the Constitution. ${ }^{69}$

\section{(ii) Related rights}

In contrast to the notion of competing values, human rights are also understood to be mutually reinforcing. The principle of 'interdependency' has therefore been recognised and endorsed in various human rights instruments. ${ }^{70}$ This discourse has found a particular place in the realm of so-called second-generation rights and is similarly sound when one talks about

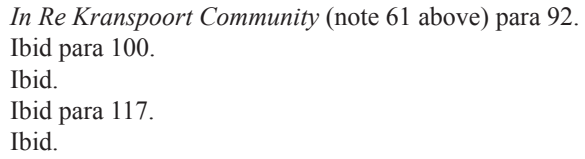
mentions in principle 2 that the environmental right and other human rights, including civil, cultural, economic, political and social rights, are universal, interdependent and indivisible. See also the Vienna Declaration and Programme of Action, adopted by the World Conference on Human Rights, June 1993, UN Doc A/Conf 157/23, Part I, para 5. 
third-generation rights, such as the environmental right. ${ }^{71}$ This principle of interdependency is understood to operate within a dual context. ${ }^{72}$ First, in the organic sense, one right forms a part of another right and might therefore be incorporated into that latter right. Thus one (core) right justifies the other (derivative) right. In $S v$ Makwanyane ${ }^{73}$ Justice O'Regan stated: 'The right to life, thus understood, incorporates the right to dignity. So the rights to human dignity and life are entwined. The right to life is more than existence - it is a right to be treated as a human being with dignity: without dignity, human life is substantially diminished. Without life, there cannot be dignity. ${ }^{74}$

However, in Soobramoney $v$ Minister of Health (Kwazulu-Natal), ${ }^{75}$ the Constitutional Court had to determine whether denial of access to medical services infringed the right to life of the applicant. The court concluded that the right to life was not at stake in this particular case, and indicated that the Constitutional Court was unlikely to adopt this approach, which is favoured by the Indian Courts:

Unlike the Indian Constitution ours deals specifically in the Bill of Rights with certain positive obligations imposed on the state, and where it does so, it is our duty to apply the obligations as formulated in the Constitution and not draw inferences that would be inconsistent therewith. ${ }^{76}$

One author correctly noted that this approach is at odds with the principle of the interdependency of rights and that 'the express inclusion of socio-economic rights should not have the effect of draining the right to life and human dignity of substantive content. ${ }^{, 77}$ The view of the court in this case is in fact at odds with its earlier decisions such as $S v$ Makwanyane. It suggests that socioeconomics should be viewed in a different light from other civil and political rights such as the right to dignity. While civil and political rights are capable of being inter-related, socio-economic rights are therefore excluded from this interpretation by reason of their express inclusion in the Constitution. This reasoning is clearly untenable.

Secondly, interdependence may also be understood in the sense of its related rights or related interdependence, in terms of which the rights in question are mutually reinforcing or mutually dependent, but distinct. In Case of Lopez

71 In the aftermath of the Second World War international legal instruments embodied the notion of universal human rights. The first set of rights recognised in the Universal Declaration of Human Rights (1948) and later in the United Nations Covenant on Civil and Political Rights (1966) were the so-called first generations rights, namely civil and political rights. More recently the so-called second generation rights, which are socio-economic rights and environmental rights, were recognised in the United Nations Covenant on Economic, Social and Cultural Rights.

72 C Scott 'The Interdependence and Permeability of Human Right Norms: Towards a Partial Fusion of the International Covenants on Human Rights' (1989) 27 Osgoode Hall LJ 769, 779-783.

731995 (3) SA 391 (CC).

74 Ibid para 327.

751998 (1) SA 765 (CC).

76 Ibid para 15.

77 Liebenberg (note 23 above) 41-31. 
Ostra $v$ Spain $^{78}$ for example, the European Court found that severe environmental pollution by a waste treatment plant could constitute an interference with a person's home, private and family life. This form of related interdependence has also been recognised by the South African Constitutional Court in Khumalo $v$ Holomisa. ${ }^{79}$ O'Regan J made the following observation:

It should also be noted that there is a close link between human dignity and privacy in our constitutional order. The right to privacy, entrenched in s 14 of the Constitution, recognises that human beings have a right to a sphere of intimacy and autonomy that should be protected from invasion. This right serves to foster human dignity. No sharp lines then can be drawn between reputation, dignitas and privacy in giving effect to the value of human dignity in our Constitution. ${ }^{80}$

An opportune moment arose to assess the relationship between property rights, freedom of expression and the environmental right. In Petro Props (Pty) Ltd $v$ Barlow, ${ }^{81}$ Barlow, together with an environmental association dedicated to the preservation of a wetland area, publicly opposed the development of a fuel service station in a wetlands area. The respondent opposed the development primarily because it was taking place in an ecologically sensitive area. The applicant was the owner of an immovable property on which, having obtained all the necessary consents, it was constructing a fuel service station and a convenience store. The project was backed by a major national petrochemical concern, Sasol (Pty) Ltd (Sasol), and the viability of the project depended on Sasol's backing. Barlow's opposition took the form of an ongoing public campaign against the development, a campaign that had been 'successful' to the extent that it had brought Sasol to the brink of withdrawing its backing of the project.

The applicant therefore sought to interdict the respondent from continuing her campaign to prevent it from exercising its rights in respect of its property, in particular its right to construct a service station and convenience store. The applicant's primary argument was that it had a right to construct a petrol station on its own property and that throughout the campaign, it had been persistently and unlawfully harassed by the respondent. It contended that its fundamental property rights under $\mathrm{s} 25^{82}$ of the Constitution had to prevail over the respondents' fundamental right to freedom of expression under s $16^{83}$ of the Constitution. Barlow contended that she and her associates had a consti-

(1) No one may be deprived of property except in terms of law of general application, and no law may permit arbitrary deprivation of property.

83 Section 16(1) states:

(1) Everyone has the right to freedom of expression, which includes-

(a) freedom of the press and other media;

(b) freedom to receive or impart information or ideas;

(c) freedom of artistic creativity; and

(d) academic freedom and freedom of scientific research. 
tutional right under s 16 to conduct the campaign and to question the process whereby the applicant had secured the necessary consent. She furthermore also relied on s 24, to which the applicant responded that the terms of this environment right mean that it is the state alone which must give effect to it, and that it therefore operated against the respondents, whose active pursuit of a campaign such as this one was thereby excluded.

While the Court upheld Barlow's defence, it chose not to consider any of the arguments raised vis-à-vis s 24. The Court's reasoning focused on the opposing claims raised in terms of the rights to property and the right to freedom of expression, relegating s 24 to a footnote which noted that in the context of this case, the environment right in s 24 is subsumed under a debate on freedom of expression'. ${ }^{84}$ This scant reference to s 24 is wholly insufficient. After all, Barlow and the Libradene Wetland Association's expression of dissatisfaction with the actions of the applicant were motivated first and foremost by environmental considerations, their concerns about the threat of degradation to an ecologically sensitive wetland. The context for their protest is more appropriately articulated, therefore, in s 24 and their right to an environment that is free from degradation. The Court acknowledged the environmental interest which drove the expression of the respondents in its application of a two-stage analysis in which the first step assessed the degree to which the constitutional protection of expression extends to the protection of the respondents' campaign. It noted the 'selfless' interest and motivation of the respondents, aimed at contributing to environmental protection in the common good. ${ }^{85}$ It failed, however, to relate this motivation to the environmental right.

On the face of it, the relationship between freedom of expression and environmental rights seemed tenuous. This relationship has to be reviewed, however, in the context of the growing tendency in South Africa to file defamation lawsuits against citizens and public interests groups that publicly object to conduct that threatens the environment. These types of defamation lawsuits are often brought by powerful entities (with deep pockets) against their less powerful (and moneyed) critics, to intimidate and hopefully silence them by debilitating them with the cost of defending a defamation claim. These types of lawsuits effectively rob citizens of their right to participate actively in political processes and seriously curtail the right to freedom of opinion. These lawsuits go beyond this, however, and are instituted because citizens attempt to protect their right to a healthy, safe and non-degraded environment. It therefore directly implicates the environmental right, and as such the Barlow case warranted much deeper and more thorough analysis of the interdependent nature of the right to freedom of expression and the environmental right. 


\section{CONCLUSION}

The insertion of an environmental right into a constitution elevates the importance of the environment and of environmental protection and conservation. It places it on a par with other constitutionally-protected rights such as equality, dignity and the right to life. The inclusion of this right in the South African constitution underscores the significance which South Africans place on a sound and healthy environment. It is also indicative of an anthropocentric choice for environmental protection, one which accepts the interconnected nature of the relationship between humans and the environment and the important role that humans fulfil in nature. It is also an approach which accepts that severe degradation of the environment can ultimately threaten human life and that as such the environmental right serves as the foundation for basic human existence.

As pointed out, the inclusion of an environmental right in a constitution has not been free of opposition, especially with reference to the alleged vague nature of the right. While this criticism may not necessarily be unfounded, it can be addressed. In the South African context we have thus far addressed questions of lack of clarity and vagueness primarily by way legislative means, primarily in fulfilment of the duty spelt out in s 24(b). However, the content of the right and its value in a developing country, which grapple with highlycontested interests such as economic development versus environmental protection, remain undefined.

What role, then, should our judiciary play in the enforcement of s 24 ? The important role of this institution was emphasised in Fuel Retailers Association recently when Ngcobo J stated: 'The role of the courts is especially important in the context of the protection of the environment and giving effect to the principle of sustainable development. ${ }^{86}$ As noted, the detailed treatment of the concept of sustainable development is especially heartening, and speaks of the judiciary's willingness to engage with s 24 in a much more in-depth manner. Indeed, this type of engagement is what is now required to define s 24 in the context of the specific economic and social conditions prevalent in South Africa, including its role vis-à-vis competing and related rights.

The judiciary thus has a responsibility to assess and interpret the environmental right and to give guidance on how we should apply and adhere to the right. Equally lawyers should take up the task of ensuring that they provide courts with sound legal arguments, supported by reliable scientific evidence when raising s 24 . In this way judges and lawyers alike could contribute to the development of sound jurisprudence on environmental rights, something that we are still lacking. 